\title{
A COMPARISON OF THE RACEMIZATION CURVES FOR URINARY, EDEMA FLUID, AND BLOOD PLASMA PROTEINS ${ }^{1}$
}

\author{
By J. W. CAVETT AND R. B. GIBSON \\ (From the Biochemistry Laboratory, The State University of Iowa, Iowa City)
}

(Received for publication June 5, 1931)

INTRODUCTION

The nature and origin of the urinary proteins in albuminuria has been a subject of considerable discussion. Presumably these proteins are blood plasma proteins which have passed through the capillary wall; however, there is some evidence that they may have originated from some other source.

The urinary proteins have been compared with other body proteins such as those from blood, liver and kidney by the precipitin reaction and by the effect of the protein upon smooth muscle from an animal which has been allergically sensitized. The biological reactions are very valuable for the identification of proteins but as was cited by Woodman (1) in the case of lactalbumin and serum albumin, the precipitin and anaphalaxis reactions may not always give the true picture. It is probably wise before drawing conclusions about the identity of a protein to compare the biological reactions with both physical and chemical means of identification.

There has been some study of the optical rotations for these proteins but the results of different workers have varied considerably due to the state of purity of the proteins used. Young (2) and Hardy and Gardiner (3) have shown that variations in the $\mathrm{pH}$ at which the readings are taken cause optical rotation for protein solutions to differ. In 1909 Kossel and Weiss (4) noticed that the optical rotation for protein solutions in dilute alkali at room temperature diminished for about two weeks and then became constant. This phenomenon was called race-

1 The contents of this paper were submitted by J. W. C. as a partial fulfillment for the degree of Doctor of Philosophy. 
mization. Certain of the amino acids obtained from these racemized proteins by acid hydrolysis were found to be optically inactive whereas if obtained before racemization they were optically active. Dakin (5) ascribed this change to a keto-enol tautomerism of the $=\mathrm{CH}-\mathrm{CO}-$ groups in the protein molecule. Thus amino acids with free $\mathrm{COOH}$ groups remain optically active during racemization while those in a peptide linkage become optically inactive. By studying the optical rotations of the amino acids isolated from the protein before and after racemization he was able to learn something as to their position in the protein molecule as well as to the quantity of each acid present. This is valuable as two proteins may contain identical quantities of the various amino acids and still be different. This method was very long and tedious.

Woodman (1) noticed that the optical rotation of the protein during racemization under constant conditions, if plotted against time, gave a definite curve. He studied the racemization curves of a number of proteins in $\mathrm{N} / 4$ and $\mathrm{N} / 2$ alkali at $37^{\circ} \mathrm{C}$. and concluded that each protein has a characteristic racemization curve when obtained under the same conditions. He also showed that heat coagulation or different means of isolating the protein did not effect the curve.

It therefore appeared that to study the identity of the urinary, edema fluid and blood plasma proteins by this method would be of value.

\section{Precipitation and purification of the proteins}

In this work the proteins were obtained from blood plasma, edema fluids and nephritic urines. The $\mathrm{pH}$ at which the precipitation is carried out affects the fractionation of the proteins; therefore, the urine was adjusted to the same $\mathrm{pH}$ as that of the plasma and edema fluids, 7.4, before precipitation. The blood plasma and edema fluids which were rich in protein were diluted $1: 5$. A volume of saturated ammonium sulphate equal to one half of that of the protein solution was added with stirring. This produced one-third saturation which precipitated the fibrinogen and euglobulin. The solution was allowed to stand a few hours and filtered. In cases of nephritis this fraction was so small it was discarded.

To the above filtrate, one-third of its volume of saturated ammonium sulphate solution was added, thus bringing it to one-half 
saturation. After being allowed to stand, preferably over night, the solution was filtered on a pleated filter and the precipitate washed with half saturated ammonium sulphate solution. The half saturated filtrate was then adjusted to the point of maximum precipitation for the albumin, by adding a little more ammonium sulphate and 10 per cent acetic acid. This point was at a pH of about 5.1. After allowing to stand for 24 hours the albumin was filtered out on a pleated filter.

From this stage the two fractions were subjected to the same treatment. They were dissolved in distilled water and diluted until the solution was less than one per cent.

The proteins were heat coagulated and the $\mathrm{pH}$ adjusted to the point of maximum precipitation by adding 10 per cent acetic acid. The solution was allowed to stand until the precipitate settled and the supernatant liquid siphoned off. Hot distilled water was then added until the original volume was reached and as soon as the precipitate settled this liquid was removed by siphoning. This process was repeated until no test could be obtained for sulphate, with barium chloride, or for ammonium with Nessler's reagent. This usually required 7 or 8 changes when large beakers were used. In the above procedure it was necessary to keep the supernatant liquid at the isoelectric point of the protein. As the ammonium sulphate was removed there was a tendency for the liquid in which the protein was suspended to become acid. To prevent this a burner was placed under the beaker containing the solution, each time when a new portion of hot water was added. If the solution was turbid a drop or two of dilute sodium hydroxide was added.

The protein was next transferred to a $250 \mathrm{cc}$. centrifuge tube and centrifuged to remove as much water as possible. It was then treated, without removal from the tube, by boiling with 95 per cent alcohol three times, absolute alcohol once, absolute alcohol ether mixture once and with ether twice, the liquid being centrifuged off each time, while it was still hot in the case of the alcohol. This gave a fine white powder which appeared to be lipid free.

\section{METHOD OF RACEMIZATION}

Woodman used one gram of protein for an analysis but in the present work the procedure was modified so only 0.2 gram of protein was used. 
This did not affect the accuracy and the reading was simplified as the solution remained during racemization in the polariscope tube instead of a flask from which samples had to be taken for each reading. The protein, in a weighing bottle, was placed in a dessicator over calcium chloride for several days before the sample was weighed out. The $\mathbf{0 . 2}$ gram sample was placed in a $10 \mathrm{cc}$. volumetric flask and $4 \mathrm{cc}$. of carbon-dioxide-free water added. The flask was shaken until the protein was completely wet and dispersed into fine particles. While shaking the flask, $5 \mathrm{cc}$. of normal carbon dioxide-free sodium hydroxide was added. The contents were diluted almost to volume and placed in an incubator at $38^{\circ} \mathrm{C}$. Under these conditions solution was complete in 10 to 20 minutes and the volume was made up to $10 \mathrm{cc}$. thus giving a 2 per cent protein solution in 0.5 normal alkali. Heat coagulated proteins from which the lipids had not been thoroughly extracted gave a turbid solution with alkali and could not be used. The solution was filtered into a $5 \mathrm{~cm}$., jacketed $\mathrm{T}$ polariscope tube where it remained in an incubator throughout the racemization period. Optical rotation readings were taken every few hours at first and later only every 24 hours in a Schmidt and Haentsch polarimeter with an electric bulb and chromate filter (10 per cent potassium chromate solution, $30 \mathrm{~mm}$. thickness) as a source of light.

The experimental error in reading this type of polarimeter using 5 $\mathrm{cm}$. tubes with protein solutions is about $0.01^{\circ}$ after one's eye has become accustomed to reading. An average of several readings gave the final result. However there are times when one's eye is less sensitive and a single reading may vary as much as $0.02^{\circ}$. In this work $0.01^{\circ}$ reading on the polariscope was equivalent to $1^{\circ}$ specific rotation.

In this method of identification of a protein one is not interested so much in a single reading as in the type of curve given by all the readings. There is only a few degrees difference in the specific optical rotations of serum albumin and serum globulin. The curves start at $67^{\circ}$ and $72^{\circ}$ respectively and at 6 hours the readings are both the same, $59^{\circ}$. However the pseudoglobulin continues to drop more rapidly, its reading remaining $2^{\circ}$ or $3^{\circ}$ below those of the albumin until 55 hours at which time the curves again cross each other, the albumin readings after this being less than those of the pseudoglobulin. The curves thus given, though never more than a few degrees apart, are easily distinguished (see Chart 1). 
Lactalbumin, which is probably closely related to serum albumin, gives a curve, which could not be mistaken for the serum albumin curve, as is shown by Woodman (1). At the beginning of the racemization period in $\mathrm{N} / 4$ alkali its optical rotation is $17^{\circ}$ higher than that of serum albumin and at the end of the period it is still $3^{\circ}$ high. (In aqueous solution lactalbumin has less optical rotation than serum albumin.) These two proteins have also been shown to be different by Hartley (6) and Crowther and Raistrick (7) using the Van Slyke nitrogen distribution method.

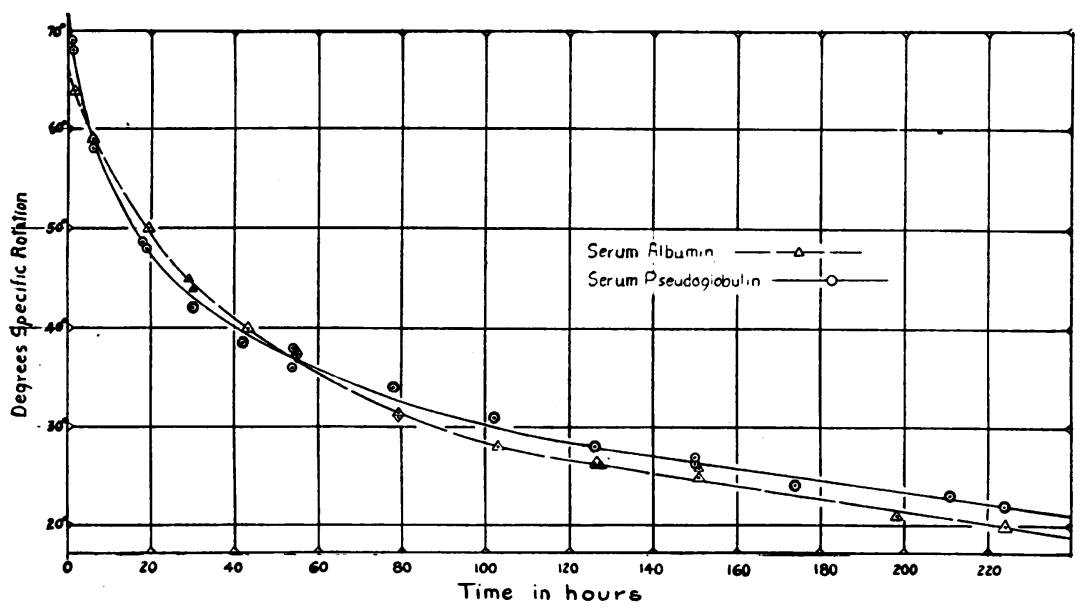

Chart 1. Racemization Curves of Serum Pseudoglobulin and Serum Albumin in $0.5 \mathrm{~N}$. $\mathrm{NaOH}$

With the technique used in this work if two proteins are identical the curves plotted from the data of either will be the same and no single reading should be over $2^{\circ}$ from this curve. Very few readings will be over $1^{\circ}$ from the curve.

\section{EXPERIMENTAL}

The proteins used in this experiment were obtained from the following cases.

Case I. J. D., number C1128, age 19, diagnosed as chronic diff use glomerular nephritis. A specimen of urine was obtained.

Case II. F. H., number C3568, age 41 , diagnosed as diffuse nephritis, diabetes mellitus and arteriosclerotic gangrene. A specimen of urine was obtained. The albumin-globulin ratio of the blood was $1: 1$. 
Case III. R. S., number D4616, age 32, diagnosed as subacute mixed nephritis. Specimens of urine and chest fluid were obtained. The blood protein ratio was 2.5 parts of globulin to 1 part albumin.

Case IV. E. Nu., number C2521, age 32, diagnosed as tuberculosis of the lungs. A specimen of chest fluid was obtained.

Case V. A. Er., number E339, age 58, diagnosed as portal cirrhosis. A specimen of ascitic fluid was obtained.

Case VI. V. P., number A4452, age 15, diagnosed as acute nephritis. Specimens of blood and urine were obtained. Globulin was slightly in excess of the albumin in the blood proteins.

The normal blood sample was obtained by pooling blood from four convalescent patients who had been in the hospital for peptic ulcer, heart failure, tuberculosis and a psychopathic condition respectively.

\section{Comparison of the proteins by racemization}

Two series of readings were taken upon the racemization of both the serum pseudoglobulin and the serum albumin. These are given in Chart 1. Racemizations for each protein were made in duplicate except for the chest fluid albumin of R. S. of which there was enough material for one determination only. Three sets of readings were taken on the urine albumin of J. D. as the second set, due to an error, gave a curve about two degrees lower than the other two curves. The nephritic blood from V. P. was not entirely lipid free. This delayed the solution of the protein and the filtration so that the first reading which was not obtained until six hours later, was $5^{\circ}$ lower than that of normal serum albumin. The presence of lipids in proteins lowers the optical rotation. This solution remained turbid throughout the period making reading difficult and inaccurate. Therefore this data was disregarded in drawing conclusions.

The racemization curves of the urine albumin from R. S., F. H., J. D., and V. P. (Charts 2 and 3) are similar to the curves given by serum albumin. The data obtained from the chest fluid albumin of R. S. and Nu. (Chart 4) and from the ascitic fluid of Er. (Chart 3) when plotted give curves similar to that of serum albumin. It appears from these data that the albumins from these various sources are serum albumin.

The pseudoglobulins obtained from the urine of the above patients, when racemized, gave data and curves (Charts 5 and 6) which are similar to those given by the serum pseudoglobulin. Pseudoglobulin 
from the blood of V. P., a nephritic, gave the same curve (Chart 6) as that given by normal serum pseudoglobulin, thus indicating that the blood proteins of nephritics are normal.

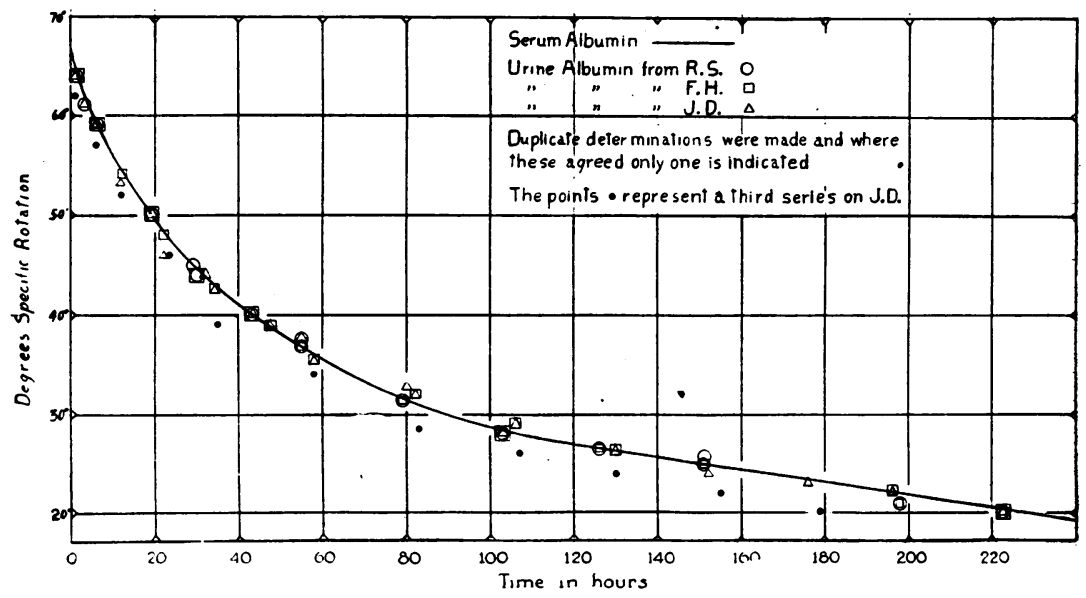

Chart 2. Racemization Curves of Urine Albumins in $0.5 \mathrm{~N}$. NaOH

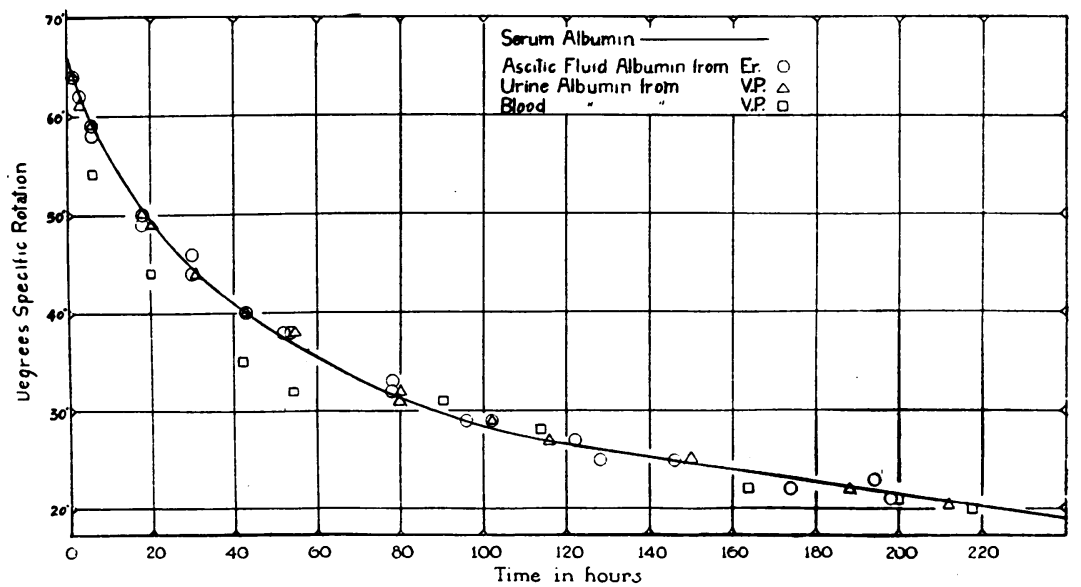

Chart 3. Racemization Curves of Albumins in $0.5 \mathrm{~N}$. $\mathrm{NaOH}$

The pseudoglobulins obtained from the ascitic fluid of Er. (Chart 6) and from the chest fluid of Nu. (Chart 7) gave data for which the greatest variation from the curve for serum pseudoglobulin was two degrees, thus being within the limits of the experimental error present 
in reading the polariscope. However if one analyses these data closely it will be noted that the curves plotted from them are not exactly identical with that of serum pseudoglobulin. The curves given by these

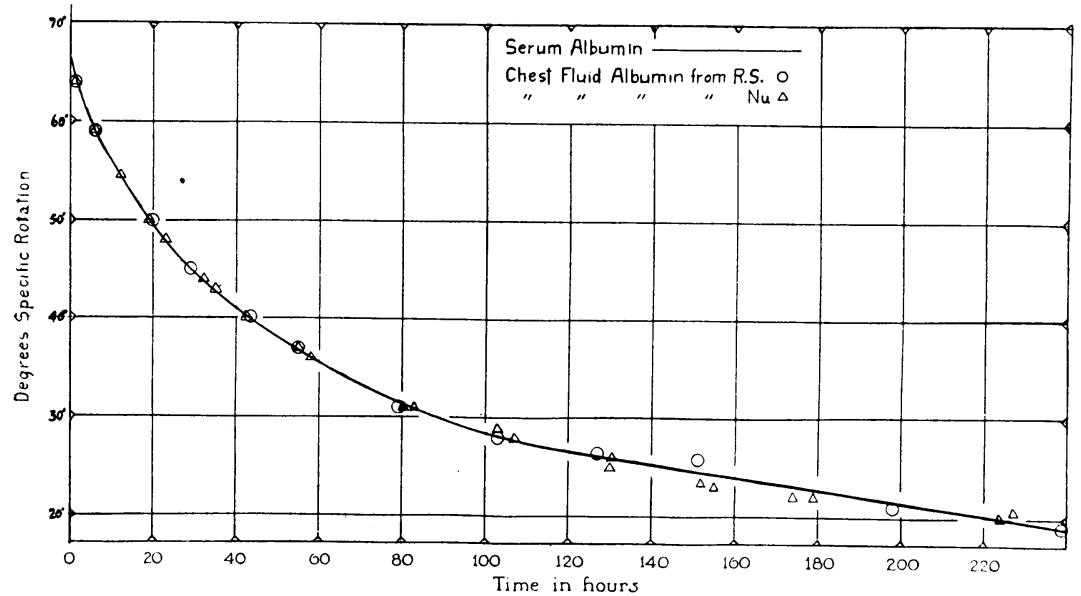

Chart 4. Racemization Curves of Edema Fluid Albumins in $0.5 \mathrm{~N}$. $\mathrm{NaOH}$

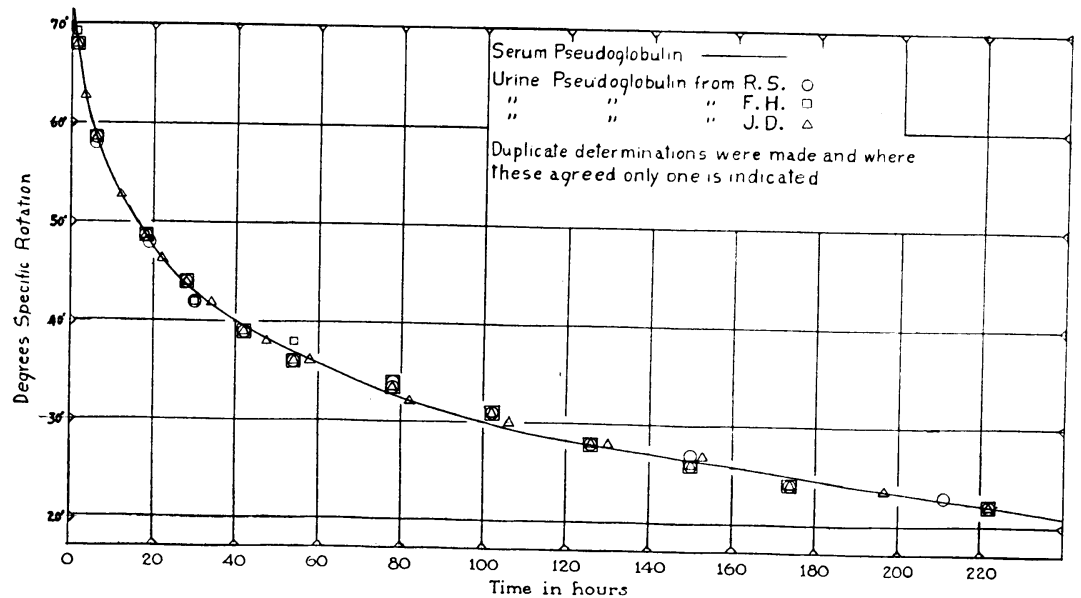

Chart 5. Racemization Curves of Urine Pseudoglobulins in $0.5 \mathrm{~N}$. $\mathrm{NaOH}$

two proteins are slightly above the normal curve at 25 to 45 hours and below it in the later part of the period. For this reason one might conclude that these proteins were not identical with the serum protein. 
However these curves suggest the possibility that serum albumin was present as an impurity and the authors feel that this was the case. Fractionation of proteins is carried out best when the solution contains

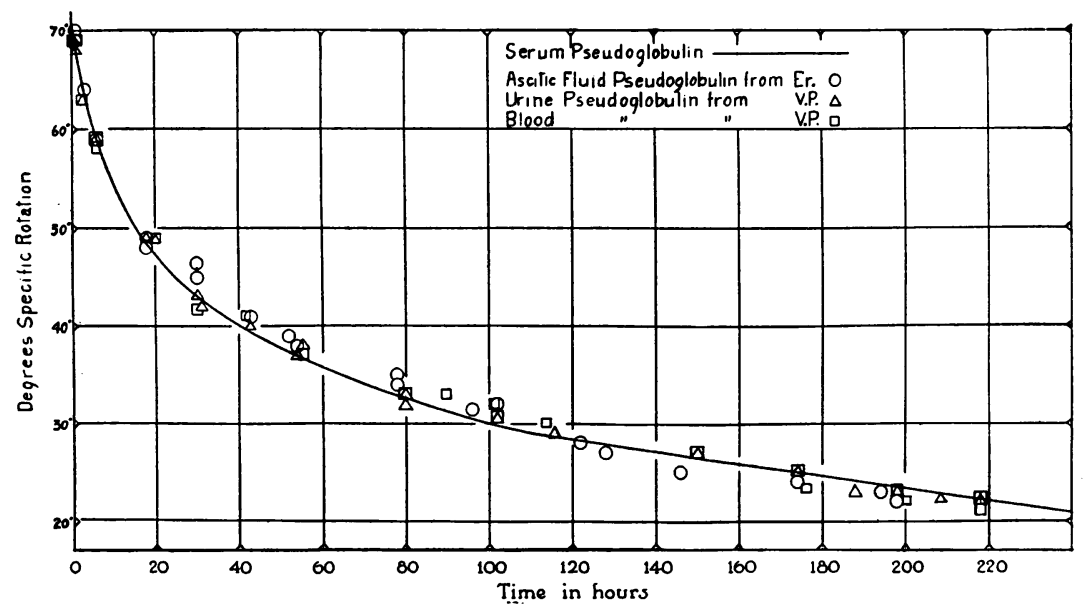

Chart 6. Racemization Curves of Pseudoglobulins in $0.5 \mathrm{~N}$. NaOH

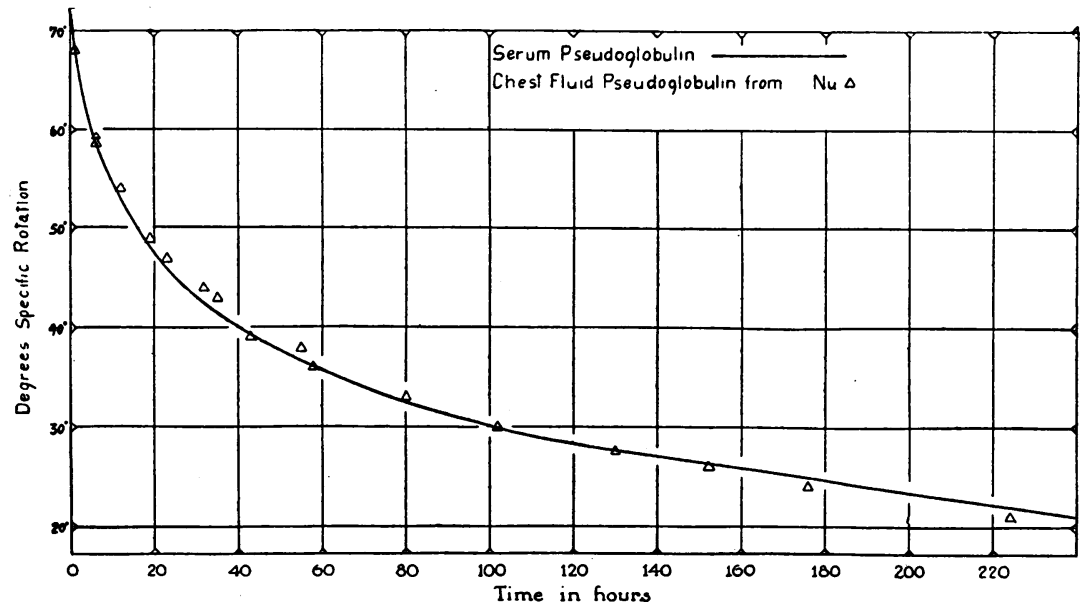

Chart 7. Racemization Curve of Edema Fluid Pseudolgobulin in $0.5 \mathrm{~N} . \mathrm{NaOH}$

about 1.5 per cent of protein. In these two instances, as was shown by the amount of protein obtained, the fluids were not diluted sufficiently before fractionation. Kauder (8) and Gibson and Banzhof (9) found 
that if blood plasma, diluted with one or two volumes of water, were fractionated with ammonium sulphate a larger quantity of protein would be precipitated at a given saturation of the salt than if the solution was more dilute. This shows that part of the next fraction is precipitated along with the desired fraction if the solution is too concentrated. Therefore one would expect these samples of pseudoglobulin to contain some albumin.

With these considerations in mind it seems that one is justified in concluding that the pseudoglobulin from these two sources is most probably serum protein as were the albumins from the same sources.

It is of interest that one of the authors is examining some of the proteins used in this experiment by means of the Van Slyke nitrogen distribution method and the results so far obtained indicate that the corresponding proteins from the different sources are identical.

\section{SUMMARY}

The method for the racemization of proteins has been modified so that only 0.2 gram is required for an analysis.

The racemization curves given by the albumins and pseudoglobulins from the nephritic urines are similar to those of the corresponding serum proteins.

Pseudoglobulin from blood of a nephritic patient gave a curve identical to that of normal blood.

The proteins of ascitic fluid and chest fluid appear to be serum proteins.

\section{BIBLIOGRAPHY}

1. Woodman, H. E., Biochem. J., 1921, xv, 187. A Comparative Investigation of the Corresponding Proteins of Cow and Ox Serum, Cow's Colostrum and Cow's Milk by the Method of Protein Racemization.

2. Young, E. G., Proc. Roy. Soc. London B, 1922, xciii, 15. On the Optical Rotatory Power of Crystalline Ovalbumin and Serum Albumin.

3. Hardy, W. B. and Gardiner, Mrs. S., J. Physiol. Proc., 1910, xl, lxviii. Proteins of Blood Plasma.

4. Kossel, A. and Weiss, F., Ztschr. f. Physiol. Chem., 1909, lix, 492. Über die Einwirkung von Alkalien auf Proteinstoffe.

5. Dakin, H. D., J. Biol. Chem., 1912-13, xiii, 357. The Racemization of Proteins and Their Derivatives Resulting from Tautomeric Change. 
6. Hartley, P., Biochem. J., 1914, viii, 541. The Determination of the Composition of the Different Proteins of Ox and Horse Serum by the Method of Van Slyke.

7. Crowther, C. and Raistrick, H., Biochem. J., 1916 x, 434. A Comparative Study of the Proteins of the Colostrum and Milk of the Cow and Their Relations to Serum Proteins.

8. Kauder, G., Arch. f. exper. Path. u. Pharmakol., 1886, xx, 411. Zur Kenntniss der Eiweisskörper des Blutserums.

9. Gibson, R. B. and Banzhaf, E. J., J. Exp. Med., 1910, xii, 411. The Quantitative Changes in the Proteins in the Blood Plasma of Horses in the Course of Immunization. 